\title{
Transatlantica
}

Revue d'études américaines. American Studies Journal

\section{Le monument naturel dans le mythe de l'Ouest chez Washington Irving, Mark Twain et Walt Whitman}

Delphine Louis-Dimitrov

\section{(2) OpenEdition}

Journals

Édition électronique

URL : http://journals.openedition.org/transatlantica/5241

DOI : 10.4000/transatlantica. 5241

ISSN : $1765-2766$

Éditeur

AFEA

Référence électronique

Delphine Louis-Dimitrov, « Le monument naturel dans le mythe de l'Ouest chez Washington Irving, Mark Twain et Walt Whitman », Transatlantica [En ligne], 1 | 2011, mis en ligne le 03 janvier 2012, consulté le 29 avril 2021. URL : http://journals.openedition.org/transatlantica/5241 ; DOI : https:// doi.org/10.4000/transatlantica.5241

Ce document a été généré automatiquement le 29 avril 2021

\section{(c) $(7)$}

Transatlantica - Revue d'études américaines est mis à disposition selon les termes de la licence Creative Commons Attribution - Pas d'Utilisation Commerciale - Pas de Modification 4.0 International. 


\title{
Le monument naturel dans le mythe de l'Ouest chez Washington Irving, Mark Twain et Walt Whitman
}

\author{
Delphine Louis-Dimitrov
}

1 Une antinomie profonde semble opposer les grands espaces de l'Ouest américain au motif du monument. Dans ses diverses dimensions - architecturale, commémorative, voire sépulcrale - ce dernier est un emblème de l'Ancien Continent et paraît incompatible avec l'image de la jeune nation américaine. L'historicité de celle-ci, qui se veut prospective, vient s'inscrire dans un espace dont le caractère sauvage est revendiqué. Pourtant, c'est bien autour du paradigme du monument que se construit l'image de l'Ouest, comme en témoigne la référence fréquente à des monuments dans le nom même de nombreux sites de l'Ouest (tels que Monument Valley, Cathedral Valley, Cathedral Rock, Temple of the Sun, Arches et Cathedral Spires, pour n'en citer que quelques-uns). Ce rapport analogique entre espace naturel et architecture s'édifie aussi dans les textes. Les trois récits de voyages qui seront étudiés ici, A Tour on the Prairies (1835) de Washington Irving, Roughing It (1872) de Mark Twain et Specimen Days (1882) de Walt Whitman mettent en lumière la fonction centrale du paradigme du monument naturel dans la construction d'un espace américain appelé à donner corps à une nation en quête de fondement organique. Ils invitent à considérer les enjeux esthétiques et politiques de la transposition de ce motif sur le sol américain.

2 Sous la plume d'Irving, Twain et Whitman, c'est paradoxalement dans un rapport d'analogie avec l'architecture européenne que se structure l'espace sauvage de l'Ouest, le paradigme du monument naturel ayant tout d'abord pour fonction de combler ce qui, face au modèle européen, apparaît comme une lacune à la fois culturelle et esthétique. Le motif du monument contribue ainsi à l'édification d'une vision unifiée et glorieuse de la nature sauvage et permet ce faisant la mise en forme d'un patrimoine naturel où s'incarnent les valeurs collectives sur lesquelles se construit l'identité singulière de la nation américaine. Si le monument naturel accomplit une fonction de patrimoine, c'est aussi en ce qu'il offre à la nation un ancrage dans les profondeurs du 
temps, ancrage géologique et métaphoriquement historique qui prend sens dans la relation d'émulation qui subsiste encore entre l'Amérique et l'Europe à la fin du $\mathrm{XIX}^{\mathrm{e}}$ siècle. Point de jonction de l'espace, de la politique et de la littérature, la monumentalité de l'Ouest se fait enfin incarnation de la démocratie américaine et, simultanément, principe d'écriture.

\section{Combler la vacance esthétique et culturelle du territoire}

3 Le motif du monument fait figure d'intrus dans la représentation de l'Ouest. L'identité américaine se construit en effet autour de l'image d'un territoire en grande partie sauvage, support d'une vision téléologique de l'histoire héritée de la conquête puritaine. Aux antipodes des associations mémorielles traditionnellement associées aux monuments européens, la nature sauvage inspire une vision prospective de l'histoire américaine. Un poème d'Archibald MacLeish, « America was promises ", publié en 1939, rappelle l'importance de l'opposition entre monument et terres sauvages dans l'image mythique et originelle que l'Amérique oppose à l'Europe :

East were the

Dead kings and the remembered sepulchres:

West was the grass.

[...]

And all beautiful

All before us

America was always promises. (MacLeish, 323-24)

Les monuments que constituent symboliquement les rois morts et les sépultures de l'Est désignent par métonymie les vieilles nations européennes, tandis que l'Amérique s'identifie à l'ouverture des terres sauvages et vacantes de l'Ouest. Or dans la première moitié du XIX ${ }^{e}$ siècle, l'Amérique fait sien le motif du monument. À cette époque où la formation de l'identité nationale représente un enjeu primordial, l'Europe constitue non seulement un vis-à-vis dans une relation d'émulation, mais aussi une grille de lecture par laquelle appréhender l'expérience américaine.

5 L'Ouest est un espace à géométrie variable qui, au fil de la progression de la Frontière, vient à recouvrir des paysages très différents - forêts luxuriantes, grandes plaines, déserts et sites rocheux du Far West. En dépit de cette disparité, le monument apparaît comme un modèle structurant dans la représentation de chacun de ces paysages et se révèle transposable de l'un à l'autre. Il est en ce sens un paradigme qui sous-tend la construction de l'image de l'Ouest. Ce motif est omniprésent dans A Tour on the Prairies, récit dans lequel Washington Irving relate son séjour sur la Frontière entrepris en 1832 en direction de Fort Gibson, dans l'actuel Oklahoma. Un rapport analogique s'établit ici entre les deux continents, le monument étant ce schème par lequel l'espace américain est abordé et surtout structuré. Lui sont comparés aussi bien les éléments saillants du relief rocheux que l'immensité plate et ouverte des plaines et du désert, investie de ces attributs du monument que sont la grandeur et la majesté. Tout au long du récit, la désignation de la prairie fait intervenir des notions d'immensité, de perfection esthétique et de grandeur morale, notions traditionnellement associées aux monuments architecturaux ${ }^{1}$. C'est cette résonance du monument et du monumental qui permet à un même paradigme de recouvrir des éléments apparemment antinomiques. 
Ainsi, alors que la découpe des blocs rocheux est assimilée aux ruines d'une forteresse mauresque (" the ruin of some Moorish castle ", 82) et la forêt à un cachot (" our "close dungeon of innumerous boughs' ", 131) ou à une cathédrale gothique («the stained windows and clustering columns of a Gothic cathedral », 33), l'arrière-plan même de ce relief acquiert une dimension monumentale :

After a toilsome march [...] we emerged upon a grand prairie. Here one of the characteristic scenes of the Far West broke upon us. An immense extent of grassy undulating, or as it is termed, rolling country with here and there a clump of trees, dimly seen in the distance like a ship at sea; the landscape deriving sublimity from its vastness and simplicity. To the south west on the summit of a hill was a singular crest of broken rocks resembling a ruined fortress. It reminded me of the ruin of some Moorish castle crowning a height in the midst of a lonely Spanish landscape. To this hill we gave the name of Cliff Castle. (A Tour on the Prairies, 82)

6 Emblème de l'Ouest (" one of the characteristic scenes of the Far West »), l'immensité océanique de la prairie sur laquelle se découpe l'image des ruines mauresques porte elle-même, du simple fait de sa vacance ("vastness and simplicity»), les attributs du monument ("grand », « sublimity»). Le regard du narrateur construit ainsi un espace réversible où le monument et le monumental se répondent pour enserrer l'espace tout entier dans un même paradigme.

7 Sans doute la monumentalité de l'Ouest vient-elle aussi contrer la perception d'une lacune à la fois culturelle et esthétique de l'espace. À l'aune de l'Europe, l'Ouest présente un manque. Tout en célébrant le caractère sauvage de la prairie, le narrateur déplore en effet qu'elle soit dépourvue de ces monuments - châteaux, clochers, tourelles - dont il situe l'archétype dans les paysages d'Europe : «It was altogether a wild scene [...]. The prairies [...] only want here and there a village spire, the battlements of a castle, or the turrets of an old family mansion rising from among the trees, to rival the most ornamented scenery of Europe. » (A Tour on the Prairies, 83-84). Comme dans Letters from an American Farmer (1782) de Crèvecœur et dans le texte fondateur de Cole, «Essay on American Scenery» (1836), l'appréhension de l'espace américain passe chez Irving par sa confrontation aux paysages culturels des nations européennes. Ceux-ci tiennent lieu de référence pour une Amérique à la recherche de son propre modèle paysager, le "paysage américain " n'étant pas une donnée mais l'objet d'une quête (Brunet-Griffith, 15).

8 Derrière le regret d'une carence, c'est aussi la nostalgie d'Irving qui s'exprime ici - nostalgie d'une Europe où il a préalablement séjourné et qui lui offre un idiome, une grille de lecture lui permettant d'appréhender l'espace et de l'orner métaphoriquement de ces monuments qui lui font défaut. L'analogie s'inscrit dans une logique de réminiscence, comme en témoigne la récurrence du verbe «to remind » qui introduit maintes figures de monuments dans le récit, par exemple l'image des ruines de forteresse mauresque dont le souvenir est éveillé par une crête rocheuse (82). L'explorateur se place paradoxalement dans une logique de pèlerinage, dont le sens est tant national qu'individuel. Le précédent que constituent ses séjours en Europe apparaît comme la métaphore du passé européen où l'aventure américaine trouve son origine. Pour l'Amérique comme pour le narrateur, l'Europe représente un système de référence auquel le présent se rapporte inévitablement.

9 Bien qu'enivré par le mouvement qui l'entraîne vers l'ouest, le narrateur de Roughing It fait lui aussi retour vers les héritages européens pour décrire son expérience, s'inspirant notamment de sites médiévaux évoqués dans The Innocents Abroad (164). Il 
perçoit ainsi Echo Canyon comme une cité médiévale, désigne ses trouées comme des rues bordées de "murs perpendiculaires" et compare ses sommets à des tours de château fort, comme si nul autre idiome que celui du monument n'était disponible pour décrire cet espace: «[Echo Canyon] was like a long, smooth, narrow street, with a gradual descending grade, and shut in by enormous perpendicular walls of coarse conglomerate, four hundred feet high in many places, and turreted like mediæval castles.» (Roughing It, 602) La désignation géologique du canyon («coarse conglomerate») se trouve ici mise au service d'une représentation imaginaire structurée autour d'un emblème de la civilisation européenne.

Combler la vacance esthétique et culturelle du territoire, c'est aussi en rendre la saisie possible. Irving évoque, a contrario, la désorientation causée par l'absence de points de repères, ainsi que l'impossibilité de structurer l'espace :

I now found myself in the midst of a lonely waste in which the prospect was bounded by undulating swells of land, naked and uniform, where, from the deficiency of land marks and distinct features an inexperienced man may become bewildered and lose his way as readily as in the wastes of an ocean. [...]

To one unaccustomed to it, there is something inexpressibly lonely in the solitude of a prairie. The loneliness of a forest seems nothing to it. There the view is shut in by trees, and the imagination is left free to picture some livelier scene beyond. But here we have an immense extent of landscape without a sign of human existence. We have the consciousness of being far, far beyond the bounds of human habitation; we feel as if moving in the midst of a desert world. [...] The silence of the waste was now and then broken by the cry of a distant flock of pelicans stalking like spectres about a shallow pool. Sometimes by the sinister croaking of a raven in the air, while occasionally a scoundrel wolf would scour off from before me and having attained a safe distance, would sit down and howl and whine with tones that gave a dreariness to the surrounding solitude. (A Tour on the Prairies, 134)

La désorientation qui menace le voyageur est synonyme d'ensauvagement («to bewilder »). À la perte des points de repère géographiques et culturels qui structurent le paysage, répond en effet le risque d'une errance aux limites de la civilisation, voire de l'humain. Tout se passe comme si la vacance ne pouvait être peuplée que par les créatures sauvages, presque fantastiques, dont le cri vient briser le silence de la prairie. Le terme de "solitude", qui désigne une étendue désertique, vient rejoindre ici son sens originel de "loneliness». La vacance de la prairie se caractérise de fait par l'absence de toute trace humaine (" an immense extent of landscape without a sign of human existence »), d'indices de passage et de mémoire du paysage. Aussi sa résistance à la description («something inexpressibly lonely ») se double-t-elle de mutisme («the silence of the waste »). Dépourvu de tout signe et de toute architecture, l'espace ne peut signifier.

12 Le rapport d'analogie avec l'architecture européenne qu'établit le paradigme du monument permet donc de structurer l'espace sauvage de l'Ouest, alors même que l'Amérique revendique le caractère incomparable de son territoire et en fait le socle d'une destinée unique, exceptionnelle, foncièrement différente de l'histoire des nations européennes.

\section{Le monument naturel comme patrimoine}

13 L'emprunt paradoxal du paradigme du monument pour désigner la wilderness l'érige en patrimoine. À la manière du patrimoine architectural où s'incarnent l'histoire et la 
culture d'un peuple, le monument naturel offre en effet une représentation symbolique à un ensemble de valeurs sur lesquelles la nation fonde son identité ainsi que la revendication d'une destinée singulière, lui permettant par là même de s'unir autour de celles-ci. Suivant la définition qu'en propose Benedict Anderson, la nation est en effet une «communauté politique imaginée», un «artefact culturel» issu des représentations collectives : «[...] nationality, or, as one might prefer to put it in view of that word's multiple significations, nation-ness, as well as nationalism, are cultural artefacts of a particular kind. » (Anderson, 4). Aussi l'image du monument contribue-telle à donner corps à la nation. De la fin de la période révolutionnaire jusqu'aux prémices de la Guerre de Sécession, l'appropriation symbolique du territoire, qui passe par la projection sur celui-ci d'un ensemble de significations et de valeurs, constitue un enjeu majeur pour une Amérique en quête de fondement organique, l'héritage laissé par les Pères fondateurs étant celui d'une identité abstraite, constitutionnelle et juridique. Le monument naturel contribue à combler cette lacune; il apparaît en effet comme l'instrument d'une appropriation symbolique de l'espace passant par la valorisation (au sens fort de désignation symbolique d'un ensemble de valeurs) et la consécration de la nature sauvage. Ce faisant, il offre à la nation ce modèle paysager si recherché, apte à donner corps à son identité singulière.

Dans les descriptions de A Tour on the Prairies, l'appropriation symbolique de l'espace s'effectue au prix de deux paradoxes, celui de la représentation du sauvage au moyen d'un emblème de la civilisation et celui de l'union dans un même paradigme des deux visages antinomiques de la Frontière, sa splendeur et son hostilité. Cette unification du sauvage se manifeste par exemple dans la description des forêts. Si leur magnificence suggère au narrateur l'image d'une cathédrale (33), leur dévastation évoque à son esprit un treillis de fer forgé : "I shall not easily forget the mortal toil, and the vexations of flesh and spirit that we underwent occasionally, in our wanderings through the cross timber. It was like struggling through forests of cast iron. » (96) Cette icône de l'architecture européenne qu'est le fer forgé offre paradoxalement une image domestiquée de la forêt, lieu ornementé jusque dans sa désolation.

Ces tensions culminent dans la représentation de l'Indien, incarnation humaine de la nature sauvage. Il se présente tantôt comme une figure de l'autre, rejeté dans un en deçà de l'humanité et donc hors de la nation, tantôt comme l'image du bon sauvage, porteur d'une pureté naturelle que l'Amérique revendique et qu'elle oppose à la corruption du contre-modèle que constituent cette fois les vieilles nations européennes (Marienstras, 176-83). En lui s'incarnent l'innocence originelle et l'hostilité qui composent les deux visages de la Frontière. Chez Irving, ces deux aspects antagonistes se rejoignent et se réconcilient dans le paradigme du monument. Représenté de manière idéalisée, l'Indien statufié apparait comme une allégorie paradoxale, un monument à la gloire de l'état sauvage : « To add to the wildness of the scene, several Osage Indians [...] were mingled among the men. Three of them came and seated themselves by our fire. They watched every thing that was going on round them in silence, and looked like figures of monumental bronze. » (35) Plus loin, sa réduction métonymique à un buste l'identifie à cet attribut qu'est sa noblesse : «I could not but admire the finely shaped heads and busts of these savages, and their graceful attitudes and expressive gestures [...].» (117). Or, même déchue de sa grandeur, la figure de l'Indien reste monumentale, comme en témoigne la description d'un personnage métis, mi-Indien mi-« homme blanc», épave ou ruine humaine («wreck», «broken to 
pieces ») qui incarne les duretés de la vie sauvage : «Though in the prime of life, and of a robust frame and apparently iron constitution yet, by his own account he was little better than a mere wreck. He was, in fact, a living monument of the hardships of wild frontier life. » (123). Du « monumental bronze » au « living monument of the hardships of wild frontier life ", l'Indien statufié demeure une allégorie de la Frontière. Cette continuité s'effectue par le jeu d'un glissement sémantique allant du sens propre du terme de monument (édifice, statue), utilisé comme comparaison ou métaphore, au sens dérivé de symbole ou d'incarnation d'une qualité abstraite. L'image unifiée du monument que présente le texte d'Irving apparait ainsi comme une construction, un fait d'écriture qui joue de glissements sémantiques pour réconcilier les aspects contradictoires de la Frontière, sa grandeur et son hostilité.

16 L'image unifiée et glorieuse du sauvage renvoie métaphoriquement à des valeurs nationales. La noblesse de la nature sauvage suggérée par le motif du monument fait contre-point à la fausse noblesse de l'aristocratie européenne, dénoncée de façon récurrente dans les textes américains depuis la période révolutionnaire et tout au long $\mathrm{du} \mathrm{xIX}^{\mathrm{e}}$ siècle. C'est une noblesse naturelle et donc compatible avec les idéaux démocratiques qui est ici revendiquée, bien qu'elle s'exprime parfois par des analogies avec des images emblématiques de la noblesse de classe, associées à l'Europe. Irving compare ainsi la prairie à un paysage architectural, labyrinthe naturel (« the labyrinths of the forest ", 129) ou parc de château :

After a gloomy and unruly night the morning dawned bright and clear, and a glorious sunshine transformed the whole landscape, as if by magic. The late dreary wilderness brightened into a fine open country with stately groves and clumps of oaks of a gigantic size, some of which stood singly as if planted for ornament and shade in the midst of rich meadows, while our horses scattered about and grazing under them gave to the whole the air of a noble park. (A Tour on the Prairies, 81)

17 La noblesse de ce parc (" fine », « stately », « ornament », « noble park ») procède de la transfiguration opérée par une lumière rédemptrice, symbole d'une transcendance divine qui, depuis la période puritaine, s'unit étroitement à l'appréhension de la nature et de la destinée américaine. La contribution des chevaux à ce tableau est également signifiante. À l'instar des Indiens devenus bustes ou statues et dont la noblesse est celle de l'homme à l'état de nature («the wild chivalry of the prairies»; "the glorious independence of man in a savage state »,28), les animaux de la prairie apparaissent ici comme les symboles d'une noblesse naturelle et sauvage. Un cheval capturé se trouve ainsi comparé, un peu plus loin, à une figure princière («A stage hero, representing the despair of a captive prince, could not have played his part more dramatically. There was absolutely a moral grandeur in it. »,94) et un bison à un monarque («[...] two or three bulls bringing up the rear, the last of whom, from his enormous size and venerable frontlet and beard of sunburnt hair, looked like the patriarch of the herd and as if he might long have reigned the monarch of the prairie. ", 135-36). En mettant en lumière la grandeur de la nature sauvage, le paradigme du monument naturel donne forme à une valeur politique, éminemment démocratique, et contribue de la sorte à l'incorporation de la nation dans l'image de l'Ouest.

18 En dépit des différences de registre majeures qui séparent les deux textes, l'interprétation démocratique de la noblesse du paysage décrit par Irving trouve un écho dans Roughing It. La description du lac Tahoe, aux chapitres 31 et 32, prend la forme d'une série de tableaux enchâssés dans une structure narrative, vignettes qui sont autant de morceaux de bravoure stylistiques composés de nombreux topoï. S'ils 
s'inspirent de traditions iconographiques disparates, leur horizon d'attente commun est celui d'une perception mythique des emblèmes de l'Ouest. Investi de valeurs nationales, érigé en symbole, le lac se fait monument.

19 Le cadrage interprétatif du paysage précède l'apparition du lac. La beauté de celui-ci, connue d'avance, est placée d'emblée sous le signe du merveilleux naturel, composante populaire de l'art paysager américain ( We had heard a world of talk about the marvellous beauty of Lake Tahoe», 649). Source d'enchantement, la noblesse doublement proclamée du paysage tient à sa monumentalité, suggérée par l'immensité de la circonférence du lac et, sur l'axe de la verticale, par des images de murs et de tours :

[...] at last the Lake burst upon us-a noble sheet of blue water lifted six thousand three hundred feet above the level of the sea, and walled-in by a rim of snow-clad mountain peaks that towered aloft full three thousand feet higher still! It was a vast oval, and one would have to use up eighty or a hundred good miles in traveling around it. As it lay there with the shadows of the mountains brilliantly photographed upon its still surface I thought it must surely be the fairest picture the whole earth affords. (Roughing It, 649-50)

20 L'horizon interprétatif de cette vision du lac, convoqué de manière très appuyée par l'image d'une toile tendue dans un cadre et par la référence explicite à la photographie, est celui de l'iconographie, avide de lacs et de montagnes, issue des grandes missions d'exploration réalisées dans les années 1860-1880. Emblème du merveilleux de l'Ouest sauvage, espace légendaire, le lac Tahoe devient alors un objet de prédilection pour les photographes et les peintres. Cette vogue, déjà engagée avant la parution de Roughing It en 1872 - comme en témoigne la présence de huit toiles représentant ce lac parmi les quarante-et-une présentées par John Ross Key lors d'une exposition en octobre 1870 (Lekisch, 108) - atteint son paroxysme dans les années qui suivent, avec notamment $A$ Storm on the Lake, Lake Tahoe (c.1873-1878) de Carleton Watkins, pour la photographie, ainsi que, pour la peinture, Reflections (Lake Tahoe) de Gilbert Munger (c. 1873-1874), Lake Tahoe (1873) de Thomas Moran, et View of Lake Tahoe Looking Across Emerald Bay (1874) de Thomas Hill.

21 Bien au-delà du simple emprunt d'un idiome en vogue, la métaphore des montagnes " photographiées » sur le lac témoigne de ce que les merveilles de l'Ouest représentées en image et diffusées à l'Est sont une réalité inscrite sur place, l'image devenant par conséquent redondance du site. L'Ouest mythique est cette photographie que le touriste peut arpenter, dont il peut faire l'expérience in situ. La réciproque cependant est que pour qui s'est abreuvé à cette culture iconographique, le paysage réel s'appréhende comme une image. D'édifice, le monument se change ironiquement en image plate, en simple surface, pour finalement se confondre avec ses représentations. Du texte d'Irving à celui de Twain, un glissement s'effectue donc de la comparaison ou métaphore architecturale à la métaphore iconique, la monumentalité du site étant alors acquise et donc plus implicite. Ce qui fait la force mythique du paysage est désormais la capacité de sa monumentalité à faire image, à se confondre avec l'image fascinante qui circule à l'Est ${ }^{2}$.

L'image ainsi contemplée par le voyageur est en fait un artefact culturel structuré autour d'un faisceau de symboles. La présence des montagnes qui enserrent le lac contribue à projeter sur le paysage des significations politiques. Emblèmes de majesté, de permanence et d'indépendance, les montagnes sont porteuses de connotations républicaines dans l'iconographie du $\mathrm{XIX}^{\mathrm{e}}$ siècle (Miller, 268). Nobles, soustraites à 
l'inconstance de la nature, elles constituent ici le cadre symbolique d'un paysage dont la grandeur tient à nouveau à sa capacité à faire image :

The forest about us was dense and cool, the sky above us was cloudless and brilliant with sunshine, the broad lake before us was glassy and clear, or rippled and breezy, or black and storm-tossed, according to Nature's mood; and its circling border of mountain domes, clothed with forests, scarred with land-slides, cloven by cañons and valleys, and helmeted with glittering snow, fitly framed and finished the noble picture. (Roughing It, 653)

L'immensité de l'espace, ainsi que les dômes montagneux qui enserrent le lac, suggèrent une monumentalité qui, bien que grandiose, ne suscite pas l'effroi du sublime burkien. C'est celle d'un sublime domestiqué, contenu, comme en témoignent le cadrage et la miniaturisation de l'image, aussi panoramique soit-elle, ainsi que la réduction des éléments naturels à un costume, voire à des accessoires. Il y a là un trait caractéristique de la peinture de la seconde moitié du XIX $x^{e}$ siècle, où William McKendree Bryant perçoit une redéfinition du sublime: celui-ci ne prend plus la forme d'un déchaînement des éléments mais devient synonyme d'autorité et de permanence: " simple, severe, unchanging grandeur » (McKendree Bryant, 81).

L'équivalence métonymique entre le paysage monumental et la nation se resserre dans la suite de la description. Leitmotiv du courant luministe qui se développe dans la seconde moitié du XIX ${ }^{\mathrm{e}}$ siècle, la surface réfléchissante du lac s'inscrit dans un cadrage interprétatif très marqué, alors que le lac se fait surface de projection du ciel étoilé : " As the darkness closed down and the stars came out and spangled the great mirror with jewels, we smoked meditatively in the solemn hush and forgot our troubles and pains. » (650). L'image se referme ici littéralement sur elle-même, sous l'effet conjugué de l'obscurité qui clôture la vision (" the darkness closed down ») et de la réflexion des étoiles sur la surface de l'eau, pour produire un paysage tautologique où le lac ne fait que redoubler l'image du ciel. Ce cadrage visuel va de pair avec un cadrage du sens, l'alliance des termes "star " et "spangled ", n'étant pas sans faire écho à un certain poème de Francis Scott Key ${ }^{3}$.

Au-delà des connotations spécifiques de ce scintillement d'étoiles, les effets de lumière associent à la monumentalité du lac un symbolisme religieux qui s'exprime dans un style précieux, chargé de topoï :

At the first break of dawn we were always up and running foot-races to tone down excess of physical vigor and exuberance of spirits. [...] While smoking the pipe of peace after breakfast we watched the sentinel peaks put on the glory of the sun, and followed the conquering light as it swept down among the shadows, and set the captive crags free. We watched the tinted pictures grow and brighten upon the water till every little detail of forest, precipice and pinnacle was wrought in and finished, and the miracle of the enchanter complete. (Roughing It, 653)

L'image que constitue métaphoriquement le paysage se compose sous les yeux des voyageurs devenus spectateurs. Le paysage semble se peindre peu à peu, s'organiser tel un cosmos qui émerge du chaos sous l'effet d'une lumière conquérante et libératrice, manifestation d'une présence divine (" the glory of the sun ", «the conquering light ») qui s'exprime aussi dans le motif puritain des commencements (« dawn »). Les registres religieux et artistique fusionnent dans la polysémie du terme " glory ", qui désigne à la fois la gloire divine et un halo de lumière. Comme dans la description du parc dans le texte d'Irving, le paysage porte les signes d'une présence providentielle qui s'enracine dans l'imaginaire puritain, où la nature est le lieu d'une théophanie indissociable de la vision téléologique de l'histoire américaine (Bercovitch, 152-53). L'expérience propre 
du narrateur cède ici la place à un faisceau d'images devenues clichés, sortes de passages obligés de la description de l'Ouest mythique.

La perception du sacré dans la nature, telle qu'elle se manifeste au XIX siècle, excède les limites de l'héritage puritain pour exprimer des enjeux romantiques et transcendantalistes qui se rejoignent dans la recherche d'une émancipation du sentiment religieux, récusant les structures qui le canalisent. Dans le prolongement de Coleridge, Emerson célèbre ainsi dans Nature (1836) l'appréhension du divin au sein de la nature: "'A Gothic Church', said Coleridge, 'is a petrified religion' » (30); "The aspect of nature is devout. [...] The happiest man is he who learns from Nature the lesson of worship. » (40). Or si la valeur spirituelle du monument religieux se trouve ainsi partiellement récusée, c'est au profit d'une célébration de la nature qui, paradoxalement, reprend à son compte le motif du monument.

La conviction que la nature constitue un texte sacré où se déchiffre la destinée providentielle de l'Amérique trouve en effet un support dans l'image de la cathédrale naturelle, particulièrement en vogue au $\mathrm{XIX}^{\mathrm{e}}$ siècle ${ }^{4}$. La comparaison d'éléments du paysage de l'Ouest (rocs ou forêts) à des piliers, voûtes ou vitraux, est récurrente dans les récits de voyages et les romans qui paraissent en Amérique à cette époque. Irving exprime ainsi le sentiment du sacré que lui inspire une forêt de l'actuel Oklahoma en la comparant à une cathédrale gothique :

We were overshadowed by lofty trees, with straight smooth trunks, like stately columns, and as the glancing rays of the sun shone through the transparent leaves, tinted with the many coloured hues of autumn, I was reminded of the effect of sunshine among the stained windows and clustering columns of a Gothic cathedral. Indeed there is a grandeur and solemnity in some of our spacious forests of the West that awaken in me the same feeling I have experienced in those vast and venerable piles, and the sound of the wind sweeping through them, supplies occasionally the deep breathings of the organ. (A Tour on the Prairies, 33)

La forêt de l'Ouest, que la nation perçoit déjà comme son patrimoine (« our spacious forests of the West »), est le lieu d'une manifestation symbolique du divin, à l'instar de la wilderness originelle des colons puritains. Cooper, dans The Pioneers, assimile de même un sous-bois partiellement déforesté à l'architecture d'un temple («[...] a wide space of many acres was cleared, which might be likened to the dome of a mighty temple, to which the maples formed the columns, their tops composing the capitals and the heavens the arch.", 224). Whitman, dans un fragment de Specimen Days intitulé "Loafing in the Woods ", utilise quant à lui la métaphore des colonnes pour désigner des pins - «the tall straight columns of the plentiful bronze-topt pines» (876). L'assimilation de la forêt à une cathédrale est tout aussi fréquente dans la peinture, en particulier dans les années 1850-18605. La photographie exploite elle aussi le thème de la cathédrale naturelle, comme en témoigne un cliché de Carleton Watkins, «Cathedral Mountain » (1865) qui, pris en direction du ciel, accentue l'immensité vertigineuse du roc (Brunet et Griffith, 29). La récurrence de cette thématique tout au long du xIXe siècle est telle que le narrateur de The Adventures of Tom Sawyer, en 1876 déjà, peut la traiter comme un cliché romantique :

It seemed glorious sport to be feasting in that wild free way in the virgin forest of an unexplored and uninhabited island, far from the haunts of men, and they said they never would return to civilization. The climbing fire lit up their faces and threw its ruddy glare upon the pillared tree trunks of their forest temple, and upon the varnished foliage and festooning vines. (Tom Sawyer, 90) 

exprimée par Irving, l'image de la cathédrale naturelle place implicitement la nature dans une antériorité par rapport à l'architecture gothique. Dans le passage de A Tour on the Prairies où survient l'image de la cathédrale, la métamorphose, sous le regard du narrateur, du végétal en minéral (des troncs en piliers de pierre) semble confirmer la notion d'une continuité entre l'architecture naturelle des forêts et la structure des cathédrales. Cette perception est explicite chez Emerson qui, dans son essai « History », soutient que le gothique plonge ses racines dans l'architecture des forêts :

The Gothic church plainly originated in a rude adaptation of the forest trees with all their boughs to a festal or solemn arcade, as the bands about the cleft pillars still indicate the green withes that tied them. No one can walk in a road cut through pine woods, without being struck with the architectural appearance of the grove, especially in winter, when the bareness of all other trees shows the low arch of the Saxons. In the woods in a winter afternoon one will see as readily the origin of the stained glass window, with which the Gothic cathedrals are adorned, in the colors of the western sky seen through the bare and crossing branches of the forest. Nor can any lover of nature enter the old piles of Oxford and the English cathedrals, without feeling that the forest overpowered the mind of the builder, and that his chisel, his saw, and plane still reproduced its ferns, its spikes of flowers, its locust, elm, oak, pine, fir, and spruce. (« History », 245-46)

C'est une double vision qui se manifeste ici, l'image de la cathédrale gothique venant se superposer à celle des bois qui en sont l'origine. L'anamnèse suscitée par la contemplation de la forêt impose au regard du promeneur l'évidence d'une généalogie du gothique, dont l'ancêtre serait l'architecture des forêts. En prêtant ainsi au gothique une origine organique, Emerson fait écho aux théories architecturales selon lesquelles les piliers et les voûtes des cathédrales gothiques s'inspirent de la convergence de la cime des arbres dans une forêt. C'est ce qu'affirmait notamment le géologue écossais James Hall dans son Essay on the Origins, History and Principles of Gothic Architecture (1813), qui développe une théorie qu'il avait avancée dès 1785 .

En dépit des contradictions qui la traversent, l'image de la cathédrale naturelle représente donc une consécration de la nature sauvage, celle-ci étant désignée non 
seulement comme origine de l'architecture gothique mais aussi comme lieu de spiritualité à part entière. Les riches forêts du continent américain paraissent ainsi pouvoir rivaliser sans peine avec les plus grandes cathédrales d'Europe qui n'en présentent somme toute qu'une imitation, aussi grandiose soit-elle. Les noms de "Cathedral Spires » et de "Cathedral Rock», choisis lors des missions géologiques de l'Ouest, respectivement en 1862 et 1863, pour désigner deux sites de la vallée de Yosemite, répondent à cette volonté qu'a alors l'Amérique d'opposer au patrimoine architectural des nations européennes un patrimoine naturel qui donne corps à son identité.

\section{Ancrer la nation dans l'histoire}

Si le patrimoine désigne l'incarnation symbolique d'un ensemble de valeurs auxquelles la nation peut s'identifier, il définit également cette dernière comme patrie, comme "pays du père »; il renvoie aux héritages, aux lignées et donc à cette profondeur historique qui fait défaut à la jeune nation. La représentation de l'Ouest au moyen du paradigme du monument naturel et en particulier de l'image de la cathédrale opère précisément cet ancrage dans l'histoire dont le besoin s'exprime si vivement tout au long $\mathrm{du} \mathrm{XIX}^{\mathrm{e}}$ siècle. Certes, la temporalité dans laquelle l'Amérique vient ainsi s'ancrer au travers des monuments n'est pas celle des communautés ; mais l'histoire naturelle se substitue symboliquement à la profondeur historique. Le statut juridique de «national monument ", défini par le Antiquities Act de 1906 - initialement conçu pour protéger des sites historiques, mais que le président Theodore Roosevelt interprète d'emblée en termes géologiques ${ }^{6}$ - témoigne ainsi de la perception du patrimoine naturel en termes d'héritage historique (antiquities).

La temporalité géologique glisse aisément du domaine scientifique à celui du mythe, faisant des monuments naturels la clef de voûte d'un imaginaire des origines dont l'importance ne cesse de croître au cours du xIX siècle. La géologie, alors en plein essor, se trouve mise au service de la logique d'émulation par laquelle s'opposent les deux continents. L'année précisément où Twain publie Roughing It, en 1872, paraît Mountaineering in the Sierra Nevada, texte dans lequel le géologue Clarence King prétend avoir trouvé la trace de cataclysmes plus anciens et plus terribles que ceux qu'ait jamais connus l'Ancien Continent (Trachtenberg, 18). L'Amérique revendique ainsi des racines plus anciennes que celles de l'Europe ; elle oppose en outre à la profondeur de l'histoire celle, bien plus profonde, de la temporalité géologique.

L'omniprésence des images de monuments naturels au $\mathrm{XIX}^{\mathrm{e}}$ siècle recouvre une fascination pour la matière minérale, des grandes parois rocheuses jusqu'aux fossiles. Dans la minéralité, c'est la profondeur de la temporalité géologique qui retient l'imagination, comme le révèlent les grandes missions d'exploration de l'Ouest des années 1860-1880, qui mêlent une logique de prospection géologique à une démarche esthétique de mise en images, par la photographie et par la peinture. François Brunet et Bronwyn Griffith, qui ont consacré une exposition aux photographies réalisées dans le cadre de ces missions par Timothy O'Sullivan, John K. Hillers, William H. Jackson et Carleton E. Watkins, soulignent que ces clichés, marqués par une profusion de vues morphologiques et de détails géologiques, nourrissent une fascination pour la monumentalité rocheuse de l'Ouest, en particulier les vues de Carleton E. Watkins, qui offrent en très grand format ou sous forme stéréoscopique l'image de gigantesques 
falaises et de dômes (Brunet et Griffith, 23, 15)7. Ils montrent aussi combien les prises de vue réalisées par ces photographes, en des sites comme Yosemite, Yellowstone, Grand Canyon, Canyon de Chelly, Mesa Verde ou les chutes de la Snake River, sacralisent les paysages en insistant sur l'immensité de l'espace et sur la verticalité des falaises, leur bichromie mettant de plus en valeur «l'aspect sculptural quasi abstrait des formations géologiques» $(51,29)$. Dans l'iconographie qui naît de ces missions d'exploration, l'approche esthétique et les considérations géologiques et environnementales apparaissent comme inextricables et dialoguent l'une avec l'autre. Les travaux de certains peintres, ceux de Thomas Moran par exemple, sont ainsi réalisés à l'occasion de missions de prospection géologique et contribuent eux-mêmes à justifier auprès des instances dirigeantes la création de parcs nationaux visant à préserver ce patrimoine naturel ${ }^{8}$.

Le vertige qui saisit le narrateur de Roughing It, du haut d'un canyon des Rocheuses ou au pied d'une falaise se jetant dans le lac Tahoe (« the steep mountain-sides rose right up aloft into space-rose up like a vast wall a little out of the perpendicular [...]» 654), ainsi que l'insistance sur la forme et la minéralité même du roc, témoignent de la fascination qu'exercent les grandes parois rocheuses. La vision de celles-ci suscite en effet une dérive dans un imaginaire historique qui se nourrit d'éléments exogènes. Elle révèle une proximité symbolique de la géologie et de l'histoire. Depuis un sommet des Rocheuses, la monumentalité des montagnes évoque ainsi un tableau historique, la scène d'une convention royale :

[...] about us was gathered a convention of Nature's Kings that stood ten, twelve and even thirteen thousand feet high-grand old fellows who would have to stoop to Mount Washington, in the twilight. [...] It seemed that we could look around and abroad and contemplate the whole great globe, with its dissolving views of mountains, seas and continents stretching away through the mystery of the summer haze. (Roughing It, 598)

Quelques lignes plus loin, l'idée de souveraineté qu'inspire au narrateur le spectacle vertigineux perçu depuis un col fait intervenir l'image d'un sultan :

At that place the upper third of one or two majestic purple domes projected above our level on either hand and gave us a sense of a hidden great deep of mountains and plains and valleys down about their bases which we fancied we might see if we could step to the edge and look over. These Sultans of the fastnesses were turbaned with tumbled volumes of cloud, which shredded away from time to time and drifted off fringed and torn, trailing their continents of shadow after them [...]. (Ibid.)

Dans ces deux passages, le vertige des hauteurs se double d'une expansion illimitée dans l'horizontalité de l'espace qui mène le regard hors cadre pour exprimer un sentiment de domination sur le continent tout entier. Par le jeu d'une analogie avec l'Ancien Continent, terre de rois et de sultans, la puissance massive du roc se convertit ici en termes de pouvoir politique ou religieux, en tout cas institutionnalisé.

41 La fusion symbolique de l'histoire et de la géologie se manifeste plus encore dans l'imaginaire minier qui hante Roughing It. Sorte de monument inversé, la mine s'ouvre vers des profondeurs géologiques aussi bien que temporelles, l'intérieur de la terre se faisant métaphore d'une antériorité historique. Les mines viennent ici s'inscrire dans une géographie symbolique qui s'organise autour de noms mythiques: une mine et la région alentour reçoivent ainsi le nom de Humboldt, explorateur qui fut l'un des premiers à cartographier ce qui allait devenir le territoire mythique des gisements d'or'. Les noms donnés aux diverses mines, réelles ou fantasmées, composent une 
isotopie qui renvoie aux mythes fondateurs et aux symboles de la nation américaine: " the Gray Eagle ", " the Columbiana » ou " the Great Republic », par exemple (Roughing It, 685). C'est une topographie de l'imaginaire national qui semble se dessiner ici, par laquelle l'histoire se convertit en termes de profondeur géologique, et réciproquement la profondeur géologique en termes historiques.

L'imaginaire géologique et minier qui s'exprime dans Roughing It se rattache aussi, hors-texte, aux conditions même de la genèse de l'œuvre de Twain et à une donnée fondamentale de son inspiration. Son écriture en effet semble prise entre deux lieux fondateurs. Le premier, bien connu, est le Mississippi, où il retourna chercher l'impulsion nécessaire à l'achèvement de Adventures of Huckleberry Finn. Le second est Quarry Farm, résidence de sa belle-famille à Elmira (New York), où il rédigea la majeure partie de ses œuvres, à commencer par RoughingIt (composé en 1870-71). Dans les bois qui entouraient le manoir, à proximité de la fameuse cabane octogonale de l'écrivain construite en 1874, se trouvait une carrière, espace onirique où Twain, dès 1870 , consacra son temps libre à faire des fouilles avec son ami Joe Goodman en vue de constituer une collection de fossiles. Comme le relate son biographe Albert Bigelow Paine,

Both of them had a poetic interest in geology, its infinite remotenesses and its testimonies. Without scientific knowledge, they took a deep pleasure in accumulating a collection, which they arranged on boards torn from an old fence, until they had enough specimens to fill a small museum. They imagined they could distinguish certain geological relations and families, and would talk about trilobites, the old Red Sandstone period, and the azoic age, or follow random speculation to far-lying conclusions, developing vague humors of phrase and fancy, having together a joyful good time. (Paine, 436)

C'est bien un imaginaire géologique qu'alimente cette passion pour les fossiles, un espace à la fois extrêmement concret et onirique donnant l'illusion de pouvoir contempler et toucher un passé enfoui dans des profondeurs immémoriales.

Dans Specimen Days, les montagnes renvoient elles aussi à une nature primitive, ainsi qu'en témoigne le fragment intitulé "America's Back-Bone». Comme chez Twain, le panorama perçu depuis un sommet des Rocheuses offre une image d'expansion qui excède le cadrage visuel que constituent les chaînes de montagnes pour irradier tout l'horizon:

I jot these lines literally at Kenosha summit, [...] 10.000 feet above sea-level. At this immense height the South Park stretches fifty miles before me. Mountainous chains and peaks in every variety of perspective, every hue of vista, fringe the view, in nearer, or middle, or far-dim distance, or fade on the horizon. We have now reach'd, penetrated the Rockies [...]; and though these chains spread away in every direction, specially north and south, thousands and thousands farther, I have seen specimens of the utmost of them, and know henceforth at least what they are, and what they look like. Not themselves alone, for they typify stretches and areas of half the globe-are, in fact, the vertebrae or back-bone of our hemisphere. As the anatomists say a man is only a spine, topp'd, footed, breasted and radiated, so the whole Western world is, in a sense, but an expansion of these mountains. In south America they are the Andes, in Central America and Mexico the Cordilleras, and in our States they go under different names. (Specimen Days, 857-58)

45 L'expansion dans l'espace se révèle ici indissociable d'une descente dans les profondeurs de l'histoire naturelle. Dans cette anatomie monumentale, l'image de la colonne vertébrale minéralisée convertit en effet les Rocheuses en immense fossile et fait coïncider le minéral et l'organique pour transformer le vestige géologique en 
centre névralgique de l'hémisphère nord, du continent américain, voire du globe tout entier. Elle convertit par ailleurs les images de murs rocheux qui pourraient constituer un cloisonnement en symbole de radiation et d'expansion horizontale. Loin de se réduire à une structure morte, le fossile apparaît ici comme le principe d'une énergie fondamentale.

Cette énergie primitive est celle de la minéralité élémentaire du roc. Specimen Days révèle une fascination pour les monolithes, pour la matière minérale perçue dans toute sa puissance - «the savage power of the scene" (fragment "An Hour on Kenosha Summit», 855). Il paraît significatif que la métaphore du monument ("dome», «natural spires, minarets, castellated perches far aloft », 856) coexiste souvent dans ce texte avec une désignation géologique («monolithic», " yellow granite», 855-56). La fascination exercée par le monolithe tient, chez Whitman, à l'union du monumental et d'une matière élémentaire, de l'immensément grand et de la pureté primitive de l'élément brut. Elle se traduit dans la syntaxe par des phrases nominales, bien que parfois immensément longues, qui explorent la monumentalité du paysage et en déclinent les attributs. Une phrase d'une douzaine de lignes suit ainsi le cours d'un canyon pour s'achever sur la vision fascinée de l'immensité et de la simplicité des monolithes: "the huge rightly-named Dome-rock-and as we dash along, others similar, simple, monolithic, elephantine. » (855). Un peu plus loin, l'énumération des formes architecturales du relief se double de celle de ses teintes : « As we speed again, the yellow granite in the sunshine, with natural spires, minarets, castellated perches far aloft-then long stretches of straight-upright palisades, rhinoceros color-then gamboge and tinted chromos. » (856). Dans ces phrases nominales, l'image se suffit à elle-même, indépendamment de toute prédication; son sens paraît immanent et la fascination qu'elle exerce, absolue.

47 La plénitude et la simplicité des monolithes renvoient à une "nature primitive» totalement dénuée de tout artifice mais qui n'en participe pas moins de cette poétique que la monumentalité de l'Ouest inspire à Whitman. Il l'évoque dans un fragment intitulé « An Egotistical Find » :

"I have found the law of my own poems," was the unspoken but more and more decided feeling that came to me as I pass'd, hour after hour, amid all this grim yet joyous elemental abandon-this plenitude of material, entire absence of art, untrammel'd play of primitive Nature [...]. (Specimen Days, 855)

À l'instar des animaux monumentaux - éléphant et rhinocéros - qui portent métaphoriquement les attributs du paysage (" elephantine », "rhinoceros color »), les monolithes sont chargés d'une énergie primitive et sauvage dont le poète fait un principe d'écriture. Ils offrent l'image de l'absolu, de l'élémentaire, du primitif. L'« absence d'art ", c'est-à-dire d'artifice et de construction, place ici le monument naturel aux antipodes du monument architectural. Mais comme le ferait celui-ci, le monument naturel, en vertu de sa minéralité élémentaire, offre à l'Amérique une profondeur temporelle inscrite dans l'espace, une mémoire visible.

Or l'historicité du monument naturel est double: à la dimension rétrospective de l'ancrage dans l'histoire s'ajoute une valeur prospective. Le verbe monere, d'où vient le terme de monument, implique déjà cette double orientation temporelle, puisqu'il associe à la mémoire une idée d'avertissement et d'exhortation, ainsi qu'une fonction d'instruction et d'inspiration. Cette polysémie se retrouve dans la notion de monument, dont l'une des acceptions, obsolète, ajoute à la fonction d'identification celle 
d'avertissement et de présage : "a thing that serves as identification; a mark, sign. Also : a thing that gives warning; a portent.» (O.E.D., article "monument», 5). Le monument est ce qui fait penser à un objet qui peut être situé dans le passé ou dans l'avenir ${ }^{10}$. Telle est précisément l'ambivalence des monolithes de l'Ouest : alors même que la minéralité élémentaire et primitive du roc renvoie à une origine immémoriale, littéralement pré-historique, ceux-ci sont chargés d'une valeur d'anticipation et d'exhortation. Les grandes parois rocheuses servent ainsi de surface de projection au discours providentialiste et eschatologique issu du puritanisme, qui trouve un nouveau souffle avec l'idéologie de la Destinée Manifeste dans les années 1840, sans pour autant s'y réduire.

50 Dans l'iconographie du XIX ${ }^{e}$ siècle, chez les peintres de la Hudson River School, c'est par une monumentalité qui se confond avec le sublime que s'exprime l'idée de providence, clef de voûte de l'inscription de l'identité américaine dans la nature. Ce symbolisme simultanément religieux et national, avec lequel joue Twain dans une description du lac Tahoe embrasé (Roughing It, 655-56), passe par la représentation d'une nature colossale, originelle et ultime. Albert Bierstadt, qui étend à l'ouest cette vision qui chez ses prédécesseurs avait pour objet les paysages de l'Est, présente par exemple dans «A storm in the Rocky Mountains. Mount Rosalie " (1866) une nature à l'image de la Création, scène du combat de l'ombre et de la lumière. L'intérêt pour la géologie qui se développe à l'occasion des grandes missions d'exploration ne fait que renforcer la perception providentialiste du relief de l'Ouest. Le caractère originel du roc semble le rattacher à un passé biblique et de ce fait justifier la mission providentielle de l'Amérique. La théorie du géologue Clarence King aboutit ainsi à l'idée que puisque la nature américaine laisse percevoir le temps de la création, elle est porteuse d'une mission divine.

51 Le paradigme du monument naturel résout donc la contradiction entre la définition de la nation par son accomplissement futur et le besoin simultané de se donner un passé, de s'ancrer dans l'histoire. C'est en vertu de ce lien intrinsèque du passé et de l'avenir dans le monument naturel que Whitman peut faire de celui-ci la métaphore même de la démocratie américaine. Si en effet l'Ouest monumental en constitue le socle nourricier, il en dit également l'accomplissement à venir. Dans un fragment de " Notes Left Over » intitulé "Monuments-The Past and Present», Whitman réinterprète l'identification de la démocratie américaine à une monumentalité prospective, court-circuitant pour ainsi dire l'étape de l'identification de la destinée nationale à la nature. L'association symbolique de la nation au territoire est alors si étroite dans l'imaginaire national qu'elle se passe de référence explicite. Aussi Whitman peut-il faire l'ellipse du monument naturel pour présenter la démocratie elle-même comme un monument à part entière :

If you go to Europe, to say nothing of Asia, more ancient and massive still, you cannot stir without meeting venerable mementos-cathedrals, ruins of temples, castles, monuments of the great, statues and paintings, far, far beyond anything America can ever expect to produce, haunts of heroes long dead, saints, poets, divinities, with deepest associations of ages. But here in the New World, while those we can never emulate, we have more than those to build, and far more greatly to build. I am not sure but the day for conventional monuments, statues, memorials, \&c., has pass'd away-and that they are henceforth superfluous and vulgar. An enlarged general superior humanity, partly indeed resulting from those, we are to build. European, Asiatic greatness are in the past. Vaster and subtler, America, combining, justifying the past, yet works for a grander future, in living democratic 
forms. Here too are indicated the paths for our national bards. Other times, other lands, have had their missions-Art, War, Ecclesiasticism, Literature, Discovery, Trade, Architecture, \&c., \&c.-but that grand future is the enclosing purport of the United States. (« Notes Left Over », 1071)

Whitman ne situe pas l'opposition entre l'Ancien et le Nouveau Continent dans la présence ou dans l'absence de monuments, mais dans la nature et l'historicité symbolique de ces derniers. Faisant écho à l'opposition que posait Thomas Cole entre les «associations" mémorielles des paysages européens ("deepest associations of ages ", écrit Whitman) et celles, ouvertes vers l'avenir, de l'espace américain, il renouvelle cette thématique en jouant sur les implications temporelles du terme de monument pour opposer au sein de cette notion deux formes d'historicité radicalement opposées. Si en effet les monuments « conventionnels » d'Europe et d'Asie sont perçus comme de simples «mementos ", autrement dit comme une mémoire morte, à l'inverse la monumentalité américaine se conçoit comme l'intégration du passé dans un accomplissement orienté vers l'avenir («Vaster and subtler, America, combining, justifying the past, yet works for a grander future, in living democratic forms $»)$. Ce que l'Amérique oppose aux monuments de l'Ancien Monde, ce ne sont pas simplement ses monuments naturels; c'est surtout sa propre monumentalité, celle de sa démocratie, qui s'ouvre vers un accomplissement futur. Le paradigme du monument se déplace ainsi de l'espace vers l'histoire. Le monument naturel cède la place au monument national - au monument qu'est la nation.

\section{"That vast Something [...] combining the real and the ideal » : du principe politique au principe d'écriture}

Dans Specimen Days, la monumentalité de l'Ouest se fait volontiers idiome politique pour désigner les principes de la démocratie américaine, son peuple ( the bulk of the people ", 868) ainsi que ses dirigeants. À l'image du monument naturel qui allie dans une même grandeur le réel et l'idéal (" that vast Something [...] combining the real and the ideal », 853), ces derniers sont à la fois communs ("average ») et immensément grands ("vast spred », «towering high »), tournés vers le réel et vers l'idéal : « Then is it not subtly they [the prairies] who have given us our leading modern Americans, Lincoln and Grant?-vast-spread, average men-their foregrounds of character altogether practical and real, yet [...] with finest backgrounds of the ideal, towering high as any. » (853-54) C'est cette analogie profonde qui fait de l'immensité de la prairie un terrain propice à l'épanouissement de la démocratie américaine : « “[...] this favor'd central area of (in round numbers) two thousand miles square seems fated to be the home both of what I would call America's distinctive ideas and distinctive realities." " (854)

54 Si l'Ouest de Whitman est bien un monument politique, ce n'est pas au sens d'un tombeau, d'un panthéon national qui serait sépulcral, mais au sens d'un lieu matriciel où s'enracine la démocratie - son socle nourricier, le lieu où s'engendrent les principes démocratiques et où naissent les grands hommes. C'est un principe de génération et de régénération sans lequel la démocratie américaine ne saurait prospérer :

Democracy most of all affiliates with the open air, is sunny and hardy and sane only with Nature-just as much as Art is. Something is required to temper both-to check them, restrain them from excess, morbidity. [...] American Democracy, in its myriad personalities, in factories, work-shops, stores, offices-through the dense 
streets and houses of cities, and all their manifold sophisticated life-must either be fibered, vitalized, by regular contact with out-door light and air and growths, farmscenes, animals, fields, trees, birds, sun-warmth and free skies, or it will certainly dwindle and pale. We cannot have grand races of mechanics, work people, and commonalty, (the only specific purpose of America,) on any less terms. I conceive of no flourishing and heroic elements of Democracy in the United States, or of Democracy maintaining itself at all, without the Nature-element forming a main part-to be its health-element and beauty-element-to really underlie the whole politics, sanity, religion and art of the New World. (Specimen Days, 925-26) occupants de la calèche de Roughing It face à l'immensité du continent est-il l'expression de ce lien étroit entre l'espace de l'Ouest et la démocratie qui se noue dans l'imaginaire national avec la première grande vague de l'expansion vers l'ouest, dans les années 1830. "Even at this day it thrills me through and through to think of the life, the gladness and the wild sense of freedom that used to make the blood dance in my veins on those fine overland mornings!» (561), conclut le narrateur après avoir évoqué l'ivresse de la traversée de l'immensité sauvage. Irving déjà célèbre la force vivifiante de l'Ouest et en proclame l'efficace politique: «We send our youth abroad to grow luxurious and effeminate in Europe; it appears to me that a previous tour on the prairies would be more likely to produce that manliness, simplicity and self dependence most in unison with our political institutions. » (44). Plus qu'une simple icône de la démocratie, l'Ouest en est l'école, le vivier, la terre nourricière. Si, suivant une logique que soulignait Montesquieu dans L'Esprit des lois, la géographie détermine l'idiosyncrasie des peuples et l'orientation politique des nations, ce n'est pas simplement une relation d'influence qui s'exprime chez les auteurs américains et en particulier chez Whitman, mais plutôt une relation organique, symbiotique, la démocratie et l'espace formant un tout vivant.

L'Ouest est une réserve d'énergie aussi bien physique et politique qu'esthétique. La revendication, récurrente au $\mathrm{XIX}^{\mathrm{e}}$ siècle, d'une littérature nationale qui parachèverait l'édifice national trouve dans le paradigme du monumental un idiome privilégié. Ainsi, Longfellow, par la voix d'un personnage de Kavanagh, A Tale (1849), appelle-t-il de ses vœux une littérature épique, à la mesure du territoire, des idées et du progrès américains :

"[...] we want a national literature commensurate with our mountains and rivers,commensurate with Niagara, and the Alleghanies, and the Great Lakes!"

[...] "We want a national epic that shall correspond to the size of the country; that shall be to all other epics what Banvard's Panorama of the Mississippi is to all other paintings, -the largest in the world!"

[...] "We want a national drama in which the scope enough shall be given to our gigantic ideas, and to the unparalleled activity and progress of our people!"

[...] "In a word, we want a national literature altogether shaggy and unshorn, that shall shake the earth, like a herd of buffaloes thundering over the prairies!" (Kavanagh, A Tale, 84-85)

Cette littérature hirsute et sauvage ("shaggy and unshorn »), à l'image des bisons qui font trembler la prairie, serait pour Longfellow l'expression la plus adéquate d'une 
nation qui considère l'immensité sauvage de son territoire comme une valeur culturelle et artistique.

Roughing It répond pour sa part à la monumentalité de l'espace par la forme hyperbolique du tall tale, récit exubérant où les faits sont amplifiés, souvent lancés d'une voix tonitruante, et où le langage s'émancipe du carcan des dictionnaires et autres grammaires. Pour le narrateur, la rencontre de l'Ouest va de pair avec un apprentissage linguistique, celui d'une langue et d'un mode d'expression (le vernaculaire et le tall tale) initialement exclus des livres (« the vigorous new vernacular of the occidental plains and mountains. ", 559). Objet encombrant, source de nombreux tourments, le dictionnaire qui leste les bagages des voyageurs se révèle inutile à la compréhension et à l'usage de cette langue dialectale découverte en chemin. L'apprentissage du tall tale et la rencontre du vernaculaire des plaines et des montagnes, auquel le récit donne ici une légitimité littéraire («And so the first question we asked the conductor whenever we got to where we were to exchange drivers, was always, "Which is him?" The grammar was faulty, maybe, but we could not know, then, that it would go into a book some day. ", 566), préparent l'exubérance et l'agrammaticalité de la langue de Huckleberry Finn, dans laquelle l'Amérique reconnaîtra a posteriori son patrimoine.

60 Faisant écho à l'appel de Longfellow, Whitman enfin, dans un fragment intitulé "Mississippi Valley Literature », en appelle aux bardes pour célébrer la mission que l'Amérique doit accomplir et réclame une écriture animée par l'énergie primitive et sauvage de l'Ouest (« a great throbbing, vital, imaginative work, or series of works, or literature [...] », 867), aux antipodes de la littérature " anachronique », " absurde » et «étriquée " (« little and cramp’d», 866) importée d’Europe. Il définit une esthétique libérée des carcans, monumentale au sens où elle emprunterait les caractéristiques du monument naturel :

The pure breath, primitiveness, boundless prodigality and amplitude, strange mixture of delicacy and power, of continence, of real and ideal, and of all original and first-class elements, of these prairies, the Rocky mountains, and of the Mississippi and Missouri rivers-will they ever appear in, and in some sort form a standard for our poetry and art? (Specimen Days, 866)

61 Cette union du réel et de l'idéal qui définit le monument naturel et la démocratie américaine est donc aussi un principe d'écriture, fréquemment revendiqué dans Specimen Days. Whitman l'explicite dans ce passage où il réclame une esthétique alliant l'immensité du territoire, assimilée au « réel », à une histoire qui relève de l'« idéal » :

[...] a great throbbing, vital, imaginative work, or series of works, or literature, in constructing which the Plains, the Prairies, and the Mississippi river [...] should be the concrete background, and America's humanity, passions, struggles, hopes, there and now [...] should furnish the lambent fire, the ideal. (Ibid.)

Cette union du réel et de l'idéal, et plus largement l'esthétique qu'inspire à Whitman (dans le fragment «An Egotistical "Find” ») la monumentalité de l'espace («I have found the law of my own poems ", 855), excèdent le symbolisme national. La verticalité des grandes parois rocheuses («the almost perpendicular sides ») et la plénitude de la matière minérale («rocks, rocks, rocks»), tout en renvoyant à un passé primitif et immémorial dont l'énergie est toujours vive et à la mission providentielle de l'Amérique, s'ouvrent vers une transcendance esthétique qui échappe à toute temporalité : 
"I have found the law of my own poems," was the unspoken but more-and-more decided feeling that came to me as I pass'd, hour after hour, amid all this grim yet joyous elemental abandon-this plenitude of material, entire absence of art, untrammel'd play of primitive Nature-the chasm, the gorge, the crystal mountain stream, repeated scores, hundreds of miles-the broad handling and absolute uncrampedness-the fantastic forms, bathed in transparent browns, faint reds and grays, towering sometimes a thousand, sometimes two or three thousand feet high -at their tops now and then huge masses pois'd, and mixing with the clouds, with only their outlines, hazed in misty lilac, visible. (Specimen Days, 855-56) Whitman dans son ensemble permet à la poétique à laquelle conduit cette émotion esthétique d'être qualifiée d'«égotiste » alors même qu'elle prend pour objet la définition d'une écriture à proprement parler américaine - « An egotistical Find » étant précisément le titre du fragment où Whitman proclame la découverte de son art poétique. L'incorporation de la démocratie dans l'espace de l'Ouest, telle qu'elle s'accomplit dans Specimen Days, ne peut fonctionner sans l'union inextricable de l'expérience esthétique, de la découverte de soi et de la célébration de l'Amérique. Dans l'image whitmanienne du monument naturel se rejoignent donc l'atemporel et l'historique, l'individu et la nation, la sensibilité et le politique.

\section{Conclusion}

Sur fond de convergence dans l'admiration des merveilles de l'Ouest, l'interprétation de la monumentalité qui ressort de ces trois récits de voyages diffère grandement de 
l'un à l'autre. L'analogie avec les monuments européens qui prédomine chez Irving cède la place chez Twain à une monumentalité qui est surtout la métaphore des temps immémoriaux de la géologie. Whitman quant à lui, tout en partageant la fascination de Twain pour les profondeurs géologiques, monumentalise non plus seulement l'espace mais surtout l'idéal démocratique qui s'y incarne et en procède. Le caractère grandiose du paysage est désormais le garant de la perpétuation de la démocratie et constitue ainsi un monument qui fait référence à l'avenir plus qu'au passé.

Les multiples visages du monument naturel et la résonance en eux de problématiques nationales témoignent de la fonction centrale de l'Ouest dans les représentations symboliques de la nation au cours du $\mathrm{XIX}^{\mathrm{e}}$ siècle. Avec la conquête et l'exploration de l'Ouest, ainsi qu'avec le sectionalisme qui à partir du milieu du siècle interdit à la Nouvelle Angleterre d'offrir une image consensuelle, le centre symbolique de la nation américaine se déplace d'est en ouest. Les espaces sauvages de l'Ouest présentent une image régénérée de la nation qui trouve précisément dans le paradigme du monument naturel un support privilégié. Les textes de Twain et de Whitman témoignent de la permanence du mythe dans la seconde moitié du siècle, alors même que l'Ouest s'ouvre peu à peu à un afflux de touristes et de voyageurs, laissant percevoir derrière l'idéal une réalité de plus en plus multiple.

Si les monuments naturels contribuent dans les trois récits à faire de l'Ouest un espace mythique, c'est d'abord parce qu'ils se présentent comme un espace atemporel, exempt des tensions de l'histoire, mais qui pourtant rend compte de l'historicité de la nation américaine, de son ancrage dans le passé et de son orientation vers un accomplissement futur; c'est aussi parce qu'ils contribuent à en édifier une image idéale et à le faire apparaître comme un lieu rêvé, comme un temple sacré, comme un territoire grandiose, simultanément originel et ultime. C'est encore parce que le paradigme du monument naturel répond à des contradictions majeures qui s'expriment dans les représentations collectives de la nation américaine, la fonction du mythe étant précisément, comme l'a montré Claude Lévi-Strauss, de résoudre ou d'occulter les tensions de l'histoire. La figure du monument unifie en effet l'espace sauvage et en réconcilie ces deux visages que sont la grandeur et l'hostilité. Elle donne sens à la définition simultanée de la nation par son ancrage dans le passé et par son accomplissement à venir. Dans son interprétation whitmanienne, elle voudrait enfin résoudre la tension entre la célébration de la nature sauvage et sa nécessaire domestication dès lors qu'il s'agit de lui imposer un cadrage ou une structure, ne seraitce que par les mots. Sans doute est-ce par la revendication d'une esthétique qui serait à l'image des monuments naturels que Specimen Days réinterprète le plus profondément le mythe de l'Ouest. Whitman exprime l'utopie d'une écriture fondamentalement monumentale qui célébrerait le sauvage, le primitif, l'élémentaire, sans leur imposer les schèmes de la civilisation. Utopie littéraire aussi bien que politique qui repose sur une contradiction sous-jacente au mythe de l'Ouest depuis l'origine - l'idée que l'on pourrait saisir la wilderness sans l'abolir. 


\section{BIBLIOGRAPHIE}

ANDERSON, Benedict, Imagined Communities, London, Verso, 1991.

AXELRAD, Allan M., « From Mountain Gothic to Forest Gothic and Luminism : Changing Representations of Landscape in the Leatherstocking Tales and in American Painting ", http:// external.oneonta.edu/cooper/articles/suny/2005suny-axelrad.html (mis en ligne en juin 2007 ; page consultée le 10 décembre 2010).

BERCOVITCH, Sacvan, The Puritan Origins of the American Self, New Haven, Yale University Press, 1975.

BRUNET, François et Bronwyn GRIFFITH, Visions de l'Ouest. Photographies de l'exploration américaine, 1860-1880, Paris, Réunion des Musées Nationaux, 2007.

COLE, Thomas Cole, « Essay on American Scenery », The American Magazine, 1, Jan. 1836, 1-12. COOPER, James Fenimore, The Pioneers [1823], in The Leatherstocking Tales I, New York, The Library of America, 1985.

CRANE, Stephen, The Red Badge of Courage [1895], New York, London, Norton, 2008.

EMERSON, Ralph Waldo, Essays and Lectures, New York, The Library of America, 1983.

FISCH, Stephan, National Approaches to the Governance of Historical Heritage over Time. A Comparative Report, Amsterdam, IOS Press, 2008.

IRVING, Washington, A Tour on the Prairies [1835], in Three Western Narratives, New York, The Library of America, 2004.

LEKISCH, Barbara, Embracing Scenes About Lakes Tahoe and Donner. Painters, Illustrators and Sketch Artists, 1855-1915, Lafayette (California), Great West Books, 2003.

LONGFELLOW, Henry Wadsworth, Kavanagh, A Tale [1849], New Haven, College \& University Press, 1965.

MACLEISH, Archibald, Collected Poems, 1917-1982, Boston, Houghton Mifflin Company, 1985.

MARIENSTRAS, Élise, Les Mythes fondateurs de la nation américaine, Paris, Maspero, 1976.

MCKENDREE BRYANT, William, Philosophy of Landscape Painting, Saint Louis, Saint Louis News Co., 1882.

MILLER, Angela, The Empire of the Eye. Landscape Representation and American Cultural Politics, 1815-1875, Ithaca, London, Cornell University Press, 1993.

PAINE, Albert Bigelow, Mark Twain, A Biography, 1835-1910, New York, London, Harper, 1912.

SAVINEL, Christine, Emily Dickinson et la grammaire du secret, Lyon, Presses Universitaires de Lyon, 1993.

SCHAMA, Simon, Landscape and Memory, New York, Vintage Books, 1995.

TRACHTENBERG, Alan, The Incorporation of America. Culture and Society in the Guilded Age, New York, Hill and Wang, 1982.

TWAIN, Mark, The Innocents Abroad. Roughing It [1869, 1972], New York, The Library of America, 1984. 
---, Life on the Mississippi and The Adventures of Tom Sawyer [1883, 1876], in Mississippi Writings, New York, The Library of America, 1982.

WHITMAN, Walt, « Notes Left Over » [1892] and Specimen Days [1882], in Complete Poetry and Collected Prose, New York, The Library of America, 1982.

\section{NOTES}

1. Ces associations sont en effet récurrentes dans le récit d'Irving: "grandeur " (33), «moral grandeur » (94), « grand» (82), «stately » (81), « high and stately $(87)$, « immense » $(82,134)$, « vast» $(33,83,87,131)$, « vastness » $(82)$, « beautiful » $(40,87,112,131)$, « magnificent » $(44,83)$, « glorious » $(65,81,87)$, « solemnity » $(33)$, « sublimity $(82)$.

2. Je dois l'interprétation proposée dans ce paragraphe à un rapporteur anonyme que je tiens à remercier ici.

3. Ce poème fut écrit en 1814 à la suite de la guerre américano-britannique de 1812, en hommage à ceux qui défendirent Fort McHenry à Baltimore et $\mathrm{y}$ firent flotter le drapeau américain, contre l'acharnement britannique. Très vite, il est mis en musique et entre dans le répertoire national en tant que chant populaire. Sa popularité s'affirme dans les années qui précèdent la Guerre de Sécession, période pendant laquelle il est joué en de multiples occasions patriotiques. Ce n'est cependant qu'en 1931 qu'il deviendra hymne national.

4. L'image de la cathédrale naturelle n'est pas propre à l'imaginaire américain. En France et en Allemagne, elle hante les lettres et la philosophie depuis la fin du xvIIIe siècle, lorsque Goethe compare la cathédrale gothique à un arbre divin qui s'élance vers le ciel, jusqu'à la fin du xIxe, où Nietzsche souligne encore l'influence des forêts sur la structure des cathédrales. Dans l'intervalle, le thème de la parenté entre la cathédrale gothique et la nature inspire de manière notoire Chateaubriand, Schelling, Hegel et Hölderlin. L'image de la cathédrale s'affirme alors comme une composante majeure de la pensée romantique et, avec la redécouverte du gothique, vient nourrir les nationalismes européens en s'érigeant en manifestation du génie d'un peuple. Voir à ce propos le développement de Jacques Darriulat: http://www.jdarriulat.net/ Introductionphiloesth/MoyenAge/Cathedrale.html (mis en ligne le 29 octobre 2007; page consultée le 10 décembre 2010).

5. Allan M. Axelrad mentionne l'importance, dans la peinture de cette époque (chez des peintres comme George Inness, Worthington Whittredge, Albert Bierstadt, Asher Durand, Martin Johnson Heade, George Hetzel, John Frederick Kensett, Thomas Moran et William Trost Richards), de la lumière filtrée par les arbres et de la présence de troncs semblables à des piliers; il souligne aussi la verticalité de nombre de ces toiles.

6. La loi de 1906 donnait au Président le pouvoir de définir les sites historiques à protéger («historic landmarks, historic and prehistoric structures, and other objects of historic or scientific interest that are situated upon the lands owned or controlled by the Government of the United States ») et visait entre autres à préserver les vestiges indiens. Or entre 1906 et 1909, le Président Roosevelt utilise cette loi pour protéger des sites naturels, comme par exemple celui du Grand Canyon. Voir à ce propos l'analyse de Stephan Fisch, National Approaches to the Governance of Historical Heritage over Time. A Comparative Report, Amsterdam, IOS Press, 2008. 205.

7. Exposition «Visions de l'Ouest: photographies de l'exploration américaine, 1860-1880", Musée d'Art américain de Giverny, 10 juillet-31 octobre 2007.

8. Le parc national de Yellowstone est créé en 1872. Parc régional depuis 1864, Yosemite devient parc national en 1890 . 
9. Alexander von Humboldt eut une influence très grande sur William Gilpin (1813-1892), qui élabora une théorie selon laquelle le centre du monde, mine d'or pur, se situait en Amérique (à Centropolis, aussi appelée Gilpintown). (Savinel, 77)

10. Monere porte la racine indo-européenne men (penser). On retrouve ce lien intrinsèque du monument avec la pensée dans le terme allemand de Denkmal (monument), qui renvoie à denken, penser.

\section{RÉSUMÉS}

Cet article s'intéresse à la fonction de l'image du monument naturel dans les représentations de l'Ouest au XIX ${ }^{\mathrm{e}}$ siècle, et plus particulièrement dans trois récits de voyages, A Tour on the Prairies de Washington Irving, Roughing It de Mark Twain et Specimen Days de Walt Whitman. Icône des vieilles nations européennes, le monument est paradoxalement omniprésent dans les représentations de l'espace sauvage et y fait figure de paradigme structurant. Il s'agit d'analyser conjointement les enjeux esthétiques et politiques de sa transposition sur le sol américain. On montrera ainsi comment ce motif autour duquel se construit le paysage de l'Ouest se fait aussi incarnation de la démocratie américaine et, simultanément, principe d'écriture.

This article deals with the image of the natural monument and considers its function in $19^{\text {th }}$ century representations of the West, especially in three travel narratives-A Tour on the Prairies by Washington Irving, Roughing It by Mark Twain and Specimen Days by Walt Whitman. An emblem of the old European nations, the monument is paradoxically omnipresent in the representations of the Western wilderness and appears as a structuring paradigm. The purpose of this reflexion is to analyse jointly the aesthetic and political implications of its transposition onto the American soil. Indeed, this motive on which the construction of the Western landscape is based also appears as the embodiment of American democracy while defining a writing principle.

\section{INDEX}

Mots-clés : Monuments, Ouest, géologie, patrimoine, nation, démocratie, cathédrale, Washington Irving, Walt Whitman, Mark Twain

Keywords : Monuments, West, geology, patrimony, nation, democracy, cathedral, Washington Irving, Walt Whitman, Mark Twain

Thèmes : Hors-thème

\section{AUTEUR}

\section{DELPHINE LOUIS-DIMITROV}

Institut Catholique de Paris, Faculté des Lettres 